\title{
IL-1 Receptor Type II Production Is Upregulated by IL-4 and IL-13, and Downregulated by IFN- $\gamma$ in Mouse Gingival Epithelial Cells
}

\author{
Y. Kamiya ${ }^{1}$, Y. Ishihara ${ }^{1}$, H. Kamei ${ }^{1}$, Y. Ozawa ${ }^{1}$, H. Mizutani ${ }^{1}$, K. Kubo ${ }^{2}$, H. Maeda ${ }^{2}$, \\ T. Noguchi ${ }^{1}$ \\ ${ }^{1}$ Department of Periodontology, School of Dentistry, Aichi-Gakuin University, Nagoya, Japan \\ ${ }^{2}$ Department of Pathology, School of Dentistry, Aichi-Gakuin University, Nagoya, Japan \\ Email: *mrbox@dpc.aichi-gakuin.ac.jp
}

Received 8 January 2014; revised 5 February 2014; accepted 13 February 2014

Copyright (C) 2014 by authors and Scientific Research Publishing Inc.

This work is licensed under the Creative Commons Attribution International License (CC BY). http://creativecommons.org/licenses/by/4.0/

(c) (i) Open Access

\section{Abstract}

Background and Objective: Interleukin-1 (IL-1) binds to 2 distinct and separate receptors, types I and II (IL-1RI and IL-1RII, respectively). The binding of IL-1 to IL-1RI induces cellular signaling and biological effects, whereas binding to IL-1RII does not induce cellular signaling and indirectly inhibits IL-1 biological activities such as that of the decoy receptor. Recently, Suzuki et al. reported that soluble IL-1RII (sIL-1RII) was detected in gingival crevicular fluid from a periodontitis patient. However, it remains unclear which cells produce sIL-1RII detected in periodontal tissues. We examined the localization of IL-1RII producing cells in gingival tissues as well as related production control mechanisms. Material and Methods: IL-1RII mRNA expression in gingival epithelial cells (GE1) was performed by real-time PCR analysis, while the amount of sIL-1RII production in supernatant from GE1 cells was examined by dot-blot analysis. Involvement of the phosphorylation of STAT6 in the signaling pathway was determined by western blot analysis. Statistical analysis was performed with Student's $t$-test. Results: Culturing with IL-4 and IL-13 significantly increased IL-1RII mRNA to levels 10.5- and 8.89-fold, respectively, above that of the control $(p<0.01)$, while addition of interferon- $\gamma$ (IFN- $\gamma$ ) significantly suppressed IL-1RII mRNA by 0.22-fold as compared to the control $(p<0.05)$. Soluble IL-1RII in the supernatant of cultured GE1 cells was increased by IL-4 and IL-13, and decreased by IFN- $\gamma$, while western blotting determines the suppression of IL-1RII production by IFN- $\gamma$. Without the addition of IL-4 or IL-13 with or without IFN- $\gamma$, P-TyrSTAT6 was not detected. Conclusion: IL-1RII mRNA expression and sIL-1RII production were increased by IL-4 and IL-13, and decreased by IFN- $\gamma$. Finally, IL-4 signaling was regulated by IFN- $\gamma$ through phosphorylation of STAT6 and IL-13 signaling blockage by IFN- $\gamma$ downstream of STAT6

\footnotetext{
${ }^{*}$ Corresponding author.
}

How to cite this paper: Kamiya, Y., et al. (2014) IL-1 Receptor Type II Production Is Upregulated by IL-4 and IL-13, and Downregulated by IFN- $\gamma$ in Mouse Gingival Epithelial Cells. Modern Research in Inflammation, 3, 37-47. 


\section{translocation.}

\section{Keywords}

\section{IL-1RII, IL-4, IL-13, IFN- $\gamma$, STAT-6}

\section{Introduction}

Subgingival biofilm plays a major role in the pathogenesis of periodontal disease by stimulating an immune response that can lead to periodontal breakdown [1] [2]. In addition to genetic and acquired risk factors that can modify host response, the susceptibility to periodontal disease, as well as its severity and progression is influenced by environmental factors [3]-[5]. Microbial challenge from antigens, LPS, and other virulence factors stimulates host responses [6], while host interactions with infectious agents induce immune system cells to release inflammatory mediators including pro-inflammatory cytokines, which can promote extracellular matrix destruction in the gingivae and stimulate bone resorption [7].

Interleukin-1 (IL-1) is an important pro-inflammatory cytokine that plays a major role in several inflammatory diseases such as rheumatoid arthritis and periodontal disease. The IL-1 family consists of 2 proteins with similar biological activities, IL- $1 \alpha$ and IL-1 $\beta$, as well as the IL-1 receptor antagonist (IL-1Ra), a non-signaling ligand. These ligands bind to 2 distinct and separate receptors, the type IL-1 receptor (IL-1RI) and IL-1RII, which are expressed in a variety of cells. Both receptors contain 3 immunoglobulin (Ig)-like domains and are classified as members of the Ig superfamily. The binding of IL- $1 \alpha$ and IL-1 $\beta$ to IL-1RI leads to cellular signaling and biological effects [8], whereas binding of those to IL-1RII does not lead to cellular signaling [9]. IL-1RII can be cleaved from the cell surface and circulate as sIL-1RII, which preferentially binds to IL-1 $\beta$, further inhibiting the activity of this cytokine [10].

IL-1RI expression was found in fibroblasts derived from inflammatory gingiva obtained from a patient with periodontal disease [11], while another study showed that human gingival fibroblasts overexpressed IL-1RII, which regulated the mRNA expression of IL-1 $\beta$ [12]. IL-1RII expression was also shown to be decreased in stromal and epithelial cells in endometrium specimens obtained from women with endometriosis as compared to healthy subjects [13], while Suzuki et al. reported that sIL-1RII was detected with IL-1 $\beta$ in gingival crevicular fluid (GCF) from patients with aggressive (AgP) and chronic periodontitis (CP), though sIL-1RII production in the AgP patients was much lower [14]. It has been reported that many cytokines in GCF are produced from gingival tissue [15] [16]. On the other hand, the IL-1RII producing mechanism in periodontal tissue remains unclear. The purpose of the present study was to clear the IL-1RII producing mechanism. We investigated mRNA expression, protein synthesis, and signal transmission in relation to Il-1RII production by using dominant IL1RII producing cells obtained from a mouse oral gingiva epithelial cell line.

\section{Material and Methods}

\subsection{Cell Cultures}

GE1 cells were established using gingival epithelial tissues from temperature-sensitive SV40 large T-antigen gene transgenic C57BL/6 mice [17]. Cells were cultured on plastic dishes in chemically defined medium (SFM101, Nissui, Tokyo, Japan), with $1 \%$ fetal bovine serum and $10 \mathrm{ng} / \mathrm{ml}$ mouse epidermal growth factor (Sigma-Aldrich Japan, Tokyo, Japan) at the recommended temperature $\left(33^{\circ} \mathrm{C}\right)$. After 5-10 passages, GE1 cells were used in the following experiments.

\subsection{RT-PCR Assay and q-PCR Analysis}

GE1 cells were separately stimulated by recombinant IL-1 $\alpha$, IL- $1 \beta$, IL-4, IL-13, and IFN- $\gamma$ (R\&D Systems, Minneapolis, MN, USA). Total cellular RNA from those cells was prepared using TRIzol reagent (Invitrogen, Carlsbad, CA, USA), according to the manufacturer's instructions, then its quality was evaluated by determining the A230/A260 and A260/A280 nm ratios with a fluorospectrometer (NanoDrop ${ }^{\circledR}$ ND-1000, NanoDrop Technologies, DE, USA). cDNA was synthesized from total RNA by extension of random primers with $200 \mathrm{U}$ of Super- 
script III (Invitrogen, Carlsbad, CA, USA). PCR was performed using an AccuPower PCR PreMix (BIONEER, Daejeon, Korea) containing specific primers at 20 pmol and amplification was done in a PCR Thermal Cycler (Takara, Tokyo, Japan). The primers used for PCR were as follows: IL-1RII, forward

5'TGCAAAGTGTTTCTGGGAAC-3', reverse 5'-ATATTGCCCCCACAACCAAG-3' $333 \mathrm{bp}$; and $\beta$-actin, forward 5'-ATGGATGACGATATCGCTGC-3', reverse 5'-GCTGGAAGGTGGACAGTGAG-3' 1020 bp. The synthesized PCR products were separated by electrophoresis on $1.2 \%$ agarose gels and visualized by ethidium bromide staining.

To quantify IL-1RII mRNA, real-time PCR was performed using an ABI Prism 7000 with TaqMan ${ }^{\circledR}$ PreDeveloped Assay Reagents Mouse IL-1RII and 18S rRNA, and TaqMan ${ }^{\circledR}$ Universal PCR master mixture (Applied Biosystems, Foster City, CA, USA). For PCR, $5 \mu \mathrm{l}$ of each sample was directly added to $45 \mu \mathrm{l}$ of a RT-PCR mixture prepared from 2x RT-PCR TaqMan ${ }^{\circledR}$ Universal PCR master mixture containing each primer at a concentration of $1 \mu \mathrm{M}$, with $2 \mathrm{mM} \mathrm{MgCl}$ and $100-\mu \mathrm{M}$ probes [18]. The cycle parameters were 10 minutes at $95^{\circ} \mathrm{C}, 40$ cycles of 15 seconds at $95^{\circ} \mathrm{C}$, and 1 minute at $60^{\circ} \mathrm{C}$. The relative amounts of mRNA for the target cytokines were determined by subtracting the $\mathrm{Ct}$ value for the gene from that for ribosome RNA $(\Delta \mathrm{Ct})$. Next, the $\Delta \mathrm{Ct}$ value for the control group was subtracted from that for the experimental group ( $\Delta \Delta \mathrm{Ct})$. The results are expressed as fold change $\left(2^{-\Delta \Delta \mathrm{Ct}}\right)$ between the control and experimental groups.

\subsection{Dot-Blot Analysis}

The amount of sIL-1RII production in supernatant fluid from cultured GE1 cells was examined using dot-blot analysis. Briefly, supernatant fluid samples (5 $\mu \mathrm{l}$ each) were spotted onto polyvinylidene difluoride (PVDF) membranes (ATTO, Tokyo, Japan) and dried at room temperature for 1 hour. The membranes were blocked with 10\% BlockAce (Yukijirushi, Sapporo, Japan)/PBS-0.05\% Tween-20 (PBST) buffer for 1 hour. After washing with PBST buffer, the membranes were incubated with a rat anti-mouse IL-1RII monoclonal antibody (R\&D Systems, Minneapolis, MN, USA) for 2 hours at room temperature and subjected to extensive washing in PBST buffer. The bound proteins were then visualized by successive incubation with HRP-conjugated mouse anti-rat secondary antibody (Invitrogen, Carlsbad, CA, USA) followed by ECL Plus western blotting detection reagents (GE Healthcare, Tokyo, Japan). Finally, the protein amount was quantified using an LAS-3000 imaging system (Fujifilm, Tokyo, Japan).

\subsection{Western Blot Analysis}

GE1 cells $\left(8 \times 10^{4} /\right.$ well $)$ were stimulated with or without IL-4, IL-13, and IFN- $\gamma$ for 15 or 60 minutes, then lysed with cell lysis buffer (Cell Signaling Technology Inc., Massachusetts, MA, USA). Cell lysates were separated using 7.5\% sodium dodecyl sulfate-polyacrylamide gel electrophoresis (SDS-PAGE) and transferred to PVDF membranes (ATTO, Tokyo, Japan). The following steps were then performed the same as in the dot-blot analysis using a goat anti-mouse tyrosine phosphorylated STAT6 (P-Tyr-STAT6) antibody (R\&D Systems, Minneapolis, MN, USA) and HRP-conjugated donkey anti-goat secondary antibody (R\&D Systems, Minneapolis, MN, USA).

\subsection{Statistical Analysis}

Data were analyzed using the SPSS II software package (SPSS Japan Inc., Tokyo, Japan). IL-1RII mRNA and sIL-1RII concentrations were compared using Student's t-test. A $p<0.05$ was considered to be significant.

\section{Results}

\subsection{IL-1RII mRNA Expression by GE1 Cells Following Cytokine Stimulation}

RT-PCR analysis indicated that IL-1RII mRNA expression from GE1 cells was increased by treatments with IL-4 and IL-13, and decreased by IFN- $\gamma$ as compared to the control cells. In contrast, that expression was not changed by stimulation with IL-1 $\alpha$ or IL-1 $\beta$ (Figure 1 ).

GE1 cells were cultured in the presence or absence of IL-4, IL-13, and IFN- $\gamma$ for 2 hours, then RNA was extracted and quantitative analysis was performed using real-time PCR. IL-1RII mRNA expression by GE1 cells was significantly increased by 10.5- and 8.89-fold after stimulation with IL-4 and IL-13 (each $100 \mathrm{ng} / \mathrm{ml}$ ), respectively, as compared with the control $(p<0.05)$. In contrast, that expression was significantly decreased by 

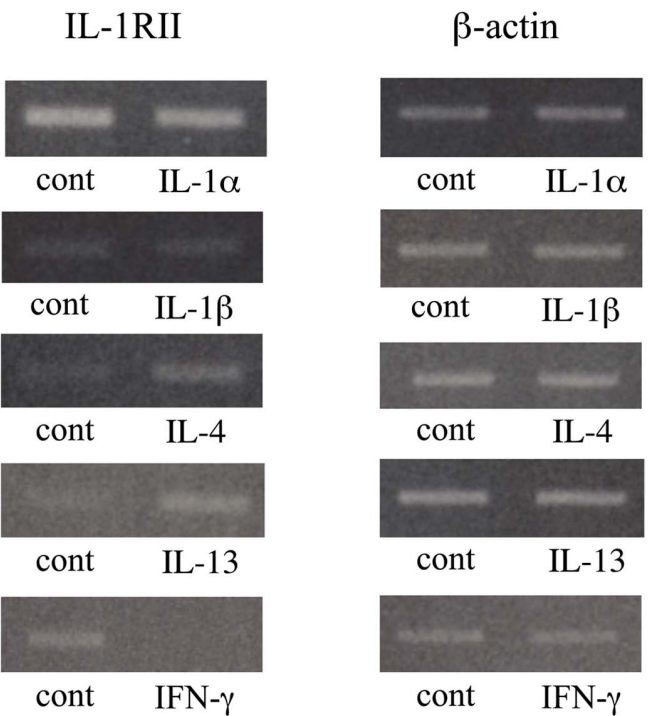

Figure 1. Expression of IL-1RII mRNA by various cytokine in mouse GE1 cells. GE1 cells were cultured at $33^{\circ} \mathrm{C}$ in the presence or absence of IL$1 \alpha, \mathrm{IL}-1 \beta, \mathrm{IL}-4, \mathrm{IL}-13$, and IFN- $\gamma(20 \mathrm{ng} / \mathrm{ml})$ for 2 hours. After harvesting, RNA was extracted and mRNA levels for IL-1RII were analyzed by RTPCR.

0.22-fold as compared with the control following stimulation with IFN- $\gamma(100 \mathrm{ng} / \mathrm{ml})(p<0.05)$ (Figure 2$)$. IL1RII mRNA expression by GE1 cells in the presence of IL-4, IL-13 (20 - $100 \mathrm{ng} / \mathrm{ml})$ were significantly increased dependent on concentration IL-4 and IL-13 (date not shown).

\subsection{Soluble IL-1RII Production from GE1 Cell Culture Supernatant Fluids}

GE1 cell culture supernatant fluids were stimulated with IL-4, IL-13, and/or IFN- $\gamma$ for 24 hours, then collected and the levels of sIL-1RII were determined using dot-blot analysis. The level of sIL-1RII was significantly increased by IL-4 and IL-13 as compared to the control (Figure 3). Those in combination also significantly increased the level of IL-1RII production by GE1 cells. However, the addition of IFN- $\gamma$ significantly decreased the level of sIL-1RII production by the cells similar to the decrease in mRNA expression seen in the previous experiment. In addition, IFN- $\gamma$ significantly decreased the level of sIL-1RII production induced by IL-4 and IL-13 stimulation.

\subsection{Suppression of P-Tyr-STAT6 by IFN- $\gamma$}

We also examined P-Tyr-STAT6, which is involved in the signaling pathways of IL-4 and IL-13, using western blotting to determine the suppression of IL-1RII production by IFN- $\gamma$. Without the addition of IL-4 or IL-13 with or without IFN- $\gamma$, P-Tyr-STAT6 was not detected (Figure 4; lane 1, 5). Furthermore, when IL-4, IL-13, and IL-4 plus IL-13 were added without IFN- $\gamma$, P-Tyr-STAT6 expression was increased (Figure 4; lane 2, 3, 4). When IL-4 was added with IFN- $\gamma$, P-Tyr-STAT6 expression was decreased as compared to IL-4 added alone (Figure 4; lane 6), while no change in expression was seen when IL-13 was added with IFN- $\gamma$ as compared with IL-13 alone (Figure 4; lane 7).

\section{Discussion}

Although IL-1RII binds to IL-1 with a strong affinity, it is unable to engage the signal transduction process, thereby preventing inflammation. IL-1RII is found in the serum of patients with sepsis, as well as epithelial cells of the endometrium of patients with endometriosis and also in patients with inflammatory diseases [13] [19]. Thus, IL1RII is an important regulator that prevents IL- $1 \beta$-mediated inflammation. 


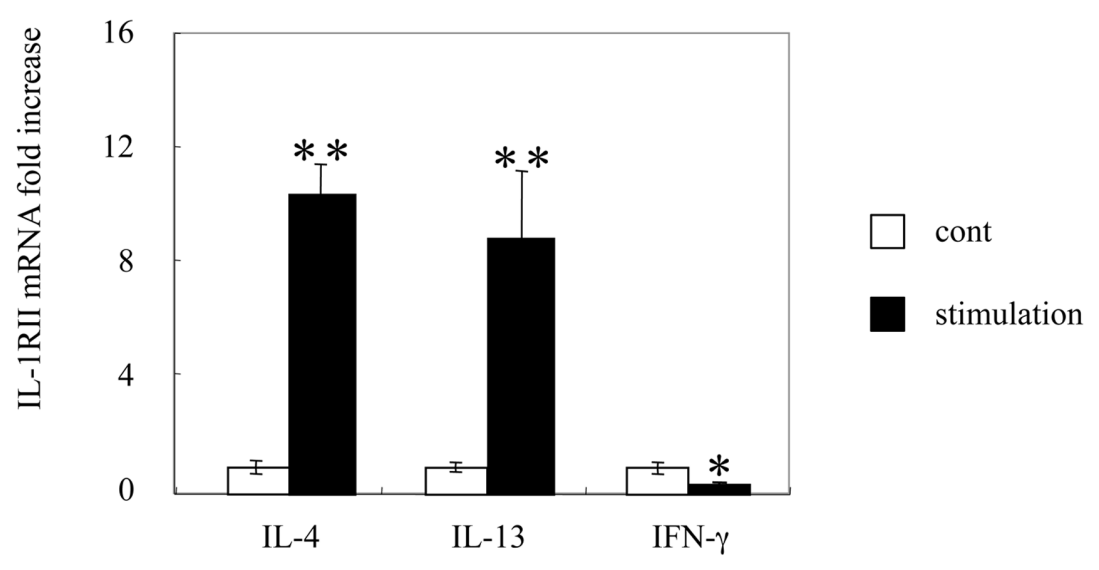

Figure 2. Effect of IL-4, IL-13 and IFN- $\gamma$ on expression of IL-1RII mRNA in mouse GE1 cells. GE1 cells were incubated for 2 hours at $33^{\circ} \mathrm{C}$ in the presence or absence of IL-4, IL-13, and IFN- $\gamma$ (100 ng/ml). After harvesting, RNA was extracted and mRNA levels for IL-1RII were analyzed by real-time PCR. Culturing with IL-4 and IL-13 significantly increased IL-1RII mRNA to levels 10.5- and 8.89-fold, respectively, above that of the control, while addition of IFN- $\gamma$ significantly suppressed IL1RII mRNA by 0.22 -fold as compared with the control. Statistical analysis was performed using Student's t-test. Results are expressed as the mean \pm SD of duplicate assays. ${ }^{*} p<0.05,{ }^{* *} p<0.01$.

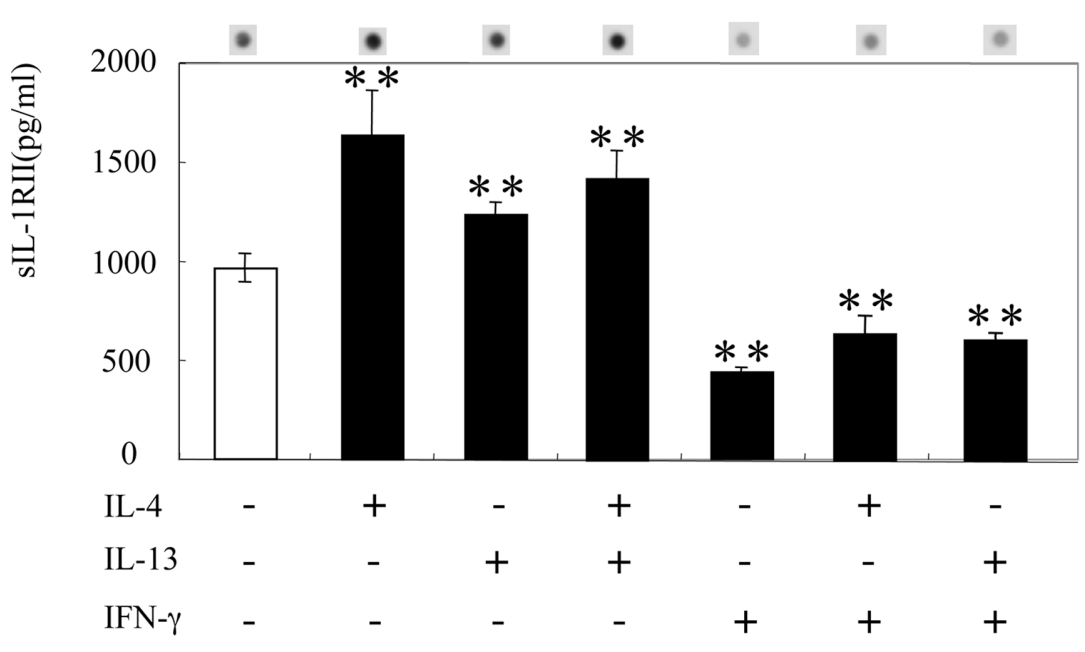
$2000 \mathrm{pg} / \mathrm{ml}$
$1000 \mathrm{pg} / \mathrm{ml}$
cont
$250 \mathrm{pg} / \mathrm{ml}$
stimulation

Figure 3. Effect of IL-4, IL-13 and IFN- $\gamma$ on sIL-1RII production in mouse GE1 cells. GE1 cells were incubated for 24 hours at $33^{\circ} \mathrm{C}$ in medium alone or with added IL-4, IL-13, and/or IFN- $\gamma(100 \mathrm{ng} / \mathrm{ml})$. At the end of the incubation period, supernatants were harvested and subjected to dot-blot assays for sIL-1RII protein. Concentration of IL-1RII production in the presence, absence of IL-4, IL-13, IL-4 plus IL-13 were $963 \mathrm{ng} / \mathrm{ml}, 1628 \mathrm{ng} / \mathrm{ml}, 1234 \mathrm{ng} / \mathrm{ml}$ and $1415 \mathrm{ng} / \mathrm{ml}$, respectively, while addition of IFN- $\gamma$, IL-4 plus IFN- $\gamma$ and IL-13 plus IFN- $\gamma$ were $441 \mathrm{ng} / \mathrm{ml}, 642 \mathrm{ng} / \mathrm{ml}$, and $616 \mathrm{ng} / \mathrm{ml}$. Statistical analysis was performed using Student's t-test. Results are expressed as the mean \pm SD of triplicate assays. ${ }^{* *} p<0.01$ (vs control). 


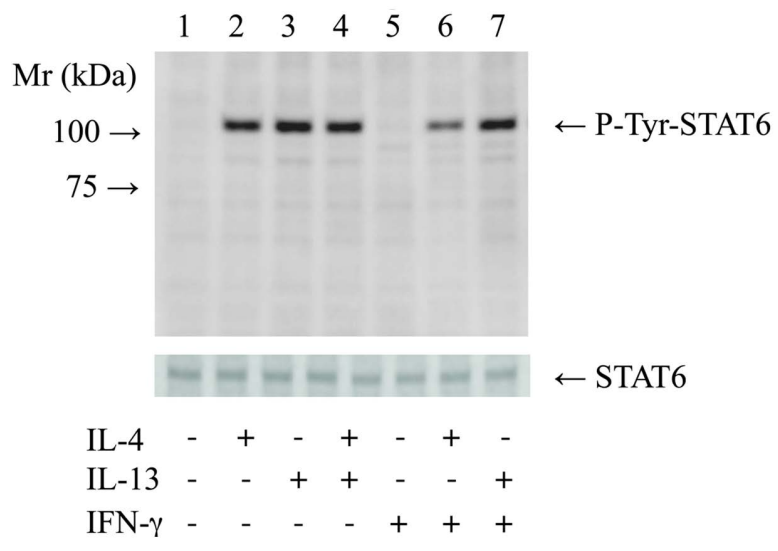

Figure 4. Effect of pretreatment with IFN- $\gamma$ on induction of tyrosine phosphorylation of STAT6 by IL-4 or IL-13. GE1 cells were pre-incubated for 1 hour at $33^{\circ} \mathrm{C}$ in medium alone or with added IFN- $\gamma(100 \mathrm{ng} / \mathrm{ml})$, then stimulated with or without IL-4 (100 ng/ml), IL-13 (100 ng/ml), or IL-4 plus IL-13 (100 ng/ml) for 15 minutes. At the end of the incubation period, the cells were lysed and assayed by western blotting with an anti-STAT6 antibody.

Immunohistological localization of IL-1RII has been observed in not only the proliferative phase but also the secretory phase in endometrial epithelial cells of healthy women [13], while its mRNA expression has been detected in neutrophils, monocytes, and B cells [20]-[22]. Gingival epithelium is in direct contact with the environment and functions as a physical barrier against bacterial invasion when periodontal pathogenic bacteria stimulated gingival epithelia, inflammatory and anti-inflammatory cytokines are produced [23] [24]. Cubitt et al. reported IL-1RII mRNA expression in corneal epithelial cells, which was enhanced by stimulation with the inflammatory cytokines IL- $1 \alpha$ and TNF- $\alpha$ [25]. It is well known that IL-1Ra production is primarily regulated by IL-1 [26]. In our study, IL-1RII was found expressed from gingival epithelium cells, indicating that IL-1RII regulates inflammatory reactions in gingival tissue in cooperation with IL-1Ra.

In a previous study, GE1 cells exhibited a phenotype characterized by non-keratinized sulcular epithelium possessing potency and undergoing keratinization in highly stratified cultures such as oral gingival epithelium, and also showed increased expression levels of IL- $1 \beta$ and TNF- $\alpha$ mRNA following stimulation with lipopolysaccharide and extracellular oral streptococci substances [17]. IL-1RII was also found localized in human gingival epithelium tissues using gingival tissues by immunohistochemical analysis (date not shown). So in this study we choose this cell line for the good cytokine production. But additional studies with gingival fibroblasts will be needed to clear the IL-1RII producing mechanism.

In the present study, IL-1RII mRNA expression was not changed when cells were stimulated with IL-1 $\alpha$ or IL- $\beta$, while IL-1RII production was upregulated by IL-4 and IL-13, which shared various biological activities including monocyte morphology, phenotype, function, and cytokine production [27] [28].

It has been reported that the Th2-type cytokine IL-4 prevents periodontitis progression [29]. Similar to IL-10, that cytokine also has marked suppressive and anti-inflammatory properties mediated by its capacity to inhibit the transcription of pro-inflammatory cytokines and IFN- $\gamma$, while it also suppresses the polarization of Th1 cells [29]-[33]. Moreover, IL-4 induces the production of cytokines with similar or complementary suppressive properties as reported for IL-10 [31] [34]. In an investigation with human tissues, IL-4 levels in gingival tissue supernatant samples were low and similar levels were found in those from periodontitis patients and healthy controls, whereas the frequency of IL-4 detection was higher in the healthy controls [35]. IL-4-producing CD4-positive $\mathrm{T}$ cells have been detected in regeneration tissue obtained from human apical periodontitis [36]. In addition, when IL-4 and IL-13 mRNA expressions in gingival tissues from patients with AgP were compared with those from healthy subjects, IL-13 was detected in the healthy subjects, while neither IL-4 nor IL-13 was detected in the patients [37]. Furthermore, other studies have noted that IL-4 induces IL-IRa production by monocytes in vitro and in vivo [38]-[41]. Together, these results suggest that IL-1RII mRNA expression and protein synthesis 
are elevated by IL-4 and IL-13 in healthy subjects, and decrease in AgP patients. In our study, culturing with IL-4 and IL-13 increased IL-1RII expression, it is considered to regulate the periodontal tissue destruction by IL-1. We have not investigated IL-1RI expression in GE1 after stimulation with IL-4 and IL-13. Additionally, it will be important to examine relationship between IL-1RI and IL-1RII of expression.

In the present study, IL-1RII expression and production were down-regulated by IFN- $\gamma$, and also reported with human monocytes [42]. IFN- $\gamma$ is the signature cytokine of Th1-type responses and considered to be the main phagocyte-activating cytokine, while it is also characteristically associated with production of inflammatory cytokines and chemokines [32] [43]-[45]. Salvi et al. noted that high levels of IFN- $\gamma$ were detected in AgP gingival crevicular fluids. As for periodontal disease, IFN- $\gamma$ is present at high levels in periodontal lesions, and associated with progressive lesions or forms of periodontitis with higher severity [46]-[48]. IFN- $\gamma$ and IL-4 have been detected in chronic and aggressive periodontal lesions, though their levels were described to be inversely correlated [49]. We previously reported that sIL-1RII was detected less frequently in the GCF of patients with AgP as compared to that of patients with chronic periodontitis [14]. These results suggest that a high level of IFN- $\gamma$ in gingival tissue of AgP patients induces a decrease in sIL-1RII levels in the GCF, which indirectly enhances the inflammatory cytokines such as IL-1 $\beta$ and induces severe tissue destruction. Moreover, Yoshinari et al. reported that clinical parameters were improved after scaling and root planning (SRP), whereas the level of IL- $1 \beta$ in GCF was found to increase and the expression of IL- $1 \beta$ mRNA remained detectable in gingival tissues after SRP [50]. Although IL-1RII binds tightly to IL-1 $\beta$, it does not elicit a biological response. IL-1RII also binds with IL- $1 \alpha$, but with significantly lower affinity, and also poorly to IL-1Ra [51]. Accordingly, an imbalance between IL-1 $\beta$ and IL-1RII might be involved in progression of periodontitis and healing of periodontal tissues after periodontal therapies, similar to the conditions seen in patients with endometriosis.

In addition to Th1 cells, recent studies have pointed out Th17 lymphocytes as an osteoclastogenic cell subset [52]. The presence of Th17 cells was demonstrated in chronic periodontal lesions [53], while Th17 cytokines, such as IL-17, IL-23, and IFN- $\gamma$, were shown to be produced in periodontal lesions [54]. In a future study, we intend to investigate the effects of those cytokines on IL-1RII expression in GE1 cells.

As for the signaling of IL-4 and IL-13, it is indispensable to activate a Janus kinase (JAK)/signal transducers and activator of transcription (STAT) pathway. STAT6 is tyrosine-phosphorylated by the JAK family because a specific ligand combines with a receptor. And it is clear for tyrosine phosphorylation of STAT6 to form a dimer, to transfer into a nucleus, and to work as a transcription factor [55].

It has also been reported that activation of the transcription factor STAT6 is essential for induction of multiple IL-4/IL-13-inducible genes, including IL-1Ra [56], Fc epsilon receptor II [57], and IL-4 receptor [58]. IL-4 and IL-13 failed to induce expression of those genes in STAT6 knock-out mice [59]-[61], and induction of STAT6 by IL-4 or Il-13 in monocytes is blocked by IFN- $\gamma$. However, induction of STAT6 by IL-4 stimulation was blocked by IFN- $\gamma$, whereas STAT6 induction by IL-13 or IL-4/IL-13 was not blocked by IFN- $\gamma$ in GE1 cells in our study. GE1 cells possess keratin 10, which is essential for terminal differentiation of keratinized epithelia and found to be expressed in the uppermost cells of confluent multilayered cultures [17]. Huang et al. also reported that keratinocyte CDw60 expression was modulated by IFN- $\gamma$, IL-4, and IL-13, while induction of STAT6 by IL-13 was not blocked by IFN- $\gamma$, the same as in our study [62]. These findings indicate that IL-13 signaling blockage by IFN- $\gamma$ occurs downstream of STAT6 translocation in GE1 cells. Baker et al. created an experimental mouse model of periodontitis that exhibits alveolar bone destruction following oral infection with periodontal pathogenic bacteria [63].

\section{Conclusion}

IL-IRII mRNA expression and sIL-1RII production from mouse GE1 cells were increased by IL-4 and IL-13, and decreased by IFN- $\gamma$. IL-4 signaling was regulated by IFN- $\gamma$ through phosphorylation of STAT6, but IL-13 signaling blockage by IFN- $\gamma$ downstream of STAT6 translocation. Based on the present results, we intend to investigate the protective role of IL-1RII against inflammatory bone resorption in periodontitis using an experimental mouse model.

\section{Acknowledgements}

This work was supported by the AGU High-Tech Research Center Project for Private Universities matching fund subsidy, 2003-2007, as a grant to Aichi Gakuin University (21592638), and a subsidy from the Strategic 
Research AGU-Platform Formation group.

\section{References}

[1] Zijnge, V., Ammann, T., Thurnheer, T. and Gmur, R. (2012) Subgingival Biofilm Structure. Frontiers of Oral Biology, 15, 1-16.

[2] Teles, R.P., Gursky, L.C., Faveri, M., Rosa, E.A., Teles, F.R., Feres, M., Socransky, S.S. and Haffajee, A.D. (2010) Relationships between Subgingival Microbiota and GCF Biomarkers in Generalized Aggressive Periodontitis. Journal of Clinical Periodontology, 37, 313-323. http://dx.doi.org/10.1111/j.1600-051X.2010.01534.x

[3] Heitz-Mayfield, L.J. (2005) Disease Progression: Identification of High-Risk Groups and Individuals for Periodontitis. Journal of Clinical Periodontology, 32, 196-209.

[4] Kinane, D.F., Peterson, M. and Stathopoulou, P.G. (2006) Environmental and Other Modifying Factors of the Periodontal Diseases. Periodontology 2000, 40, 107-119.

[5] Beck, J.D. (1994) Methods of Assessing Risk for Periodontitis and Developing Multifactorial Models. Journal of Periodontology, 65, 468-478. http://dx.doi.org/10.1902/jop.1994.65.5s.468

[6] Zambon, J.J. (1996) Periodontal Diseases: Microbial Factors. Annals of Periodontology/The American Academy of Periodontology, 1, 879-925.

[7] Suda, T., Takahashi, N., Udagawa, N., Jimi, E., Gillespie, M.T. and Martin, T.J. (1999) Modulation of Osteoclast Differentiation and Function by the New Members of the Tumor Necrosis Factor Receptor and Ligand Families. Endocrine reviews, 20, 345-357. http://dx.doi.org/10.1210/edrv.20.3.0367

[8] Sims, J.E., Gayle, M.A., Slack, J.L., Alderson, M.R., Bird, T.A., Giri, J.G., Colotta, F., Re, F., Mantovani, A., Shanebeck, K., et al. (1993) Interleukin 1 Signaling Occurs Exclusively via the Type I Receptor. Proceedings of the National Academy of Sciences of the United States of America, 90, 6155-6159. http://dx.doi.org/10.1073/pnas.90.13.6155

[9] Dinarello, C.A. (1998) Interleukin-1, Interleukin-1 Receptors and Interleukin-1 Receptor Antagonist. International Reviews of Immunology, 16, 457-499. http://dx.doi.org/10.3109/08830189809043005

[10] Clark, W., Jobanputra, P., Barton, P. and Burls, A. (2004) The Clinical and Cost-Effectiveness of Anakinra for the Treatment of Rheumatoid Arthritis in Adults: A Systematic Review and Economic Analysis. Health Technology Assessment, 8, iii-iv, ix-x, 1-105.

[11] Kanda-Nakamura, C., Izumi, Y. and Sueda, T. (1996) Increased Expression of Interleukin-1 Receptors on Fibroblasts Derived from Inflamed Gingiva. Journal of Periodontology, 67, 1267-1273. http://dx.doi.org/10.1902/jop.1996.67.12.1267

[12] Chou, H.H., Takashiba, S., Maeda, H., Naruishi, K., Nishimura, F., Arai, H., Lu, H. and Murayama, Y. (2000) Induction of Intracellular Interleukin-1 Beta Signals via Type II Interleukin-1 Receptor in Human Gingival Fibroblasts. Journal of dental research, 79, 1683-1688. http://dx.doi.org/10.1177/00220345000790090801

[13] Akoum, A., Jolicoeur, C., Kharfi, A. and Aube, M. (2001) Decreased Expression of the Decoy Interleukin-1 Receptor Type II in Human Endometriosis. The American Journal of Pathology, 158, 481-489. http://dx.doi.org/10.1016/S0002-9440(10)63990-9

[14] Suzuki, M., Ishihara, Y., Kamiya, Y., Koide, M., Fuma, D., Fujita, S., Matsumura, Y., Suga, T., Kamei, H. and Noguchi, T. (2008) Soluble Interleukin-1 Receptor Type II Levels in Gingival Crevicular Fluid in Aggressive and Chronic Periodontitis. Journal of Periodontology, 79, 495-500. http://dx.doi.org/10.1902/jop.2008.070111

[15] Konopka, L., Pietrzak, A. and Brzezinska-Blaszczyk, E. (2012) Effect of Scaling and Root Planing on Interleukin-1 Beta, Interleukin-8 and MMP-8 Levels in Gingival Crevicular Fluid from Chronic Periodontitis Patients. Journal of Periodontal Research, 47, 681-688. http://dx.doi.org/10.1111/j.1600-0765.2012.01480.x

[16] Zhao, J.J., Feng, X.P., Zhang, X.L. and Le, K.Y. (2012) Effect of Porphyromonas gingivalis and Lactobacillus acidophilus on Secretion of IL1B, IL6, and IL8 by Gingival Epithelial Cells. Inflammation, 35, 1330-1337. http://dx.doi.org/10.1007/s10753-012-9446-5

[17] Hatakeyama, S., Ohara-Nemoto, Y., Yanai, N., Obinata, M., Hayashi, S. and Satoh, M. (2001) Establishment of Gingival Epithelial Cell Lines from Transgenic Mice Harboring Temperature Sensitive Simian Virus 40 Large T-Antigen Gene. Journal of Oral Pathology \& Medicine: Official Publication of the International Association of Oral Pathologists and the American Academy of Oral Pathology, 30, 296-304.

[18] Iwata, T., Mitani, A., Ishihara, Y., Tanaka, S., Yamamoto, G., Kikuchi, T., Naganawa, T., Matsumura, Y., Suga, T., Koide, M., Sobue, T., Suzuki, T. and Noguchi, T. (2005) Actinobacillus actinomycetemcomitans Y4 Capsular Polysaccharide Induces IL-1Beta mRNA Expression through the JNK Pathway in Differentiated THP-1 Cells. Clinical and Experimental Immunology, 141, 261-269. http://dx.doi.org/10.1111/j.1365-2249.2005.02836.x

[19] Giri, J.G., Wells, J., Dower, S.K., McCall, C.E., Guzman, R.N., Slack, J., Bird, T.A., Shanebeck, K., Grabstein, K.H., Sims, J.E., et al. (1994) Elevated Levels of Shed Type II IL-1 Receptor in Sepsis. Potential Role for Type II Receptor 
in Regulation of IL-1 Responses. Journal of Immunology, 153, 5802-5809.

[20] Spriggs, M.K., Lioubin, P.J., Slack, J., Dower, S.K., Jonas, U., Cosman, D., Sims, J.E. and Bauer, J. (1990) Induction of an Interleukin-1 Receptor (IL-1R) on Monocytic Cells. Evidence That the Receptor Is Not Encoded by a T CellType IL-1R mRNA. The Journal of Biological Chemistry, 265, 22499-22505.

[21] Colotta, F., Re, F., Muzio, M., Polentarutti, N., Minty, A., Caput, D., Ferrara, P. and Mantovani, A. (1994) Interleukin-13 Induces Expression and Release of Interleukin-1 Decoy Receptor in Human Polymorphonuclear Cells. The Journal of Biological Chemistry, 269, 12403-12406.

[22] Symons, J.A., Eastgate, J.A. and Duff, G.W. (1991) Purification and Characterization of a Novel Soluble Receptor for Interleukin 1. The Journal of Experimental Medicine, 174, 1251-1254. http://dx.doi.org/10.1084/jem.174.5.1251

[23] Presland, R.B. and Jurevic, R.J. (2002) Making Sense of the Epithelial Barrier: What Molecular Biology and Genetics Tell Us about the Functions of Oral Mucosal and Epidermal Tissues. Journal of Dental Education, 66, 564-574.

[24] Bahri, R., Saidane-Mosbahi, D. and Rouabhia, M. (2010) Candida famata Modulates Toll-Like Receptor, Beta-Defensin, and Proinflammatory Cytokine Expression by Normal Human Epithelial Cells. Journal of Cellular Physiology, 222, 209-218. http://dx.doi.org/10.1002/jcp.21939

[25] Cubitt, C.L., Lausch, R.N. and Oakes, J.E. (2001) Synthesis of Type II Interleukin-1 Receptors by Human Corneal Epithelial Cells but Not by Keratocytes. Investigative Ophthalmology \& Visual Science, 42, 701-704.

[26] Tominaga, K., Habu, M., Sukedai, M., Hirota, Y., Takahashi, T. and Fukuda, J. (2004) IL-1 Beta, IL-1 Receptor Antagonist and Soluble Type II IL-1 Receptor in Synovial Fluid of Patients with Temporomandibular Disorders. Archives of Oral Biology, 49, 493-499. http://dx.doi.org/10.1016/j.archoralbio.2003.12.008

[27] de Waal Malefyt, R., Figdor, C.G., Huijbens, R., Mohan-Peterson, S., Bennett, B., Culpepper, J., Dang, W., Zurawski, G. and de Vries, J.E. (1993) Effects of IL-13 on Phenotype, Cytokine Production, and Cytotoxic Function of Human Monocytes. Comparison with IL-4 and Modulation by IFN-Gamma or IL-10. Journal of Immunology, 151, 6370-6381.

[28] Zurawski, G. and de Vries, J.E. (1994) Interleukin 13, an Interleukin 4-Like Cytokine That Acts on Monocytes and B Cells, but Not on T Cells. Immunology Today, 15, 19-26. http://dx.doi.org/10.1016/0167-5699(94)90021-3

[29] Garlet, G.P. (2010) Destructive and Protective Roles of Cytokines in Periodontitis: A Re-Appraisal from Host Defense and Tissue Destruction Viewpoints. Journal of Dental Research, 89, 1349-1363. http://dx.doi.org/10.1177/0022034510376402

[30] Agnello, D., Lankford, C.S., Bream, J., Morinobu, A., Gadina, M., O’Shea, J.J. and Frucht, D.M. (2003) Cytokines and Transcription Factors That Regulate T Helper Cell Differentiation: New Players and New Insights. Journal of Clinical Immunology, 23, 147-161.

[31] Jarnicki, A.G. and Fallon, P.G. (2003) T Helper Type-2 Cytokine Responses: Potential Therapeutic Targets. Current Opinion in Pharmacology, 3, 449-455. http://dx.doi.org/10.1016/S1471-4892(03)00077-8

[32] Appay, V., van Lier, R.A., Sallusto, F. and Roederer, M. (2008) Phenotype and Function of Human T Lymphocyte Subsets: Consensus and Issues. Cytometry. Part A: The Journal of the International Society for Analytical Cytology, 73, 975-983.

[33] Bluestone, J.A., Mackay, C.R., O’Shea, J.J. and Stockinger, B. (2009) The Functional Plasticity of T Cell Subsets. Nature Reviews. Immunology, 9, 811-816. http://dx.doi.org/10.1038/nri2654

[34] Pestka, S., Krause, C.D., Sarkar, D., Walter, M.R., Shi, Y. and Fisher, P.B. (2004) Interleukin-10 and Related Cytokines and Receptors. Annual Review of Immunology, 22, 929-979.

[35] Gorska, R., Gregorek, H., Kowalski, J., Laskus-Perendyk, A., Syczewska, M. and Madalinski, K. (2003) Relationship between Clinical Parameters and Cytokine Profiles in Inflamed Gingival Tissue and Serum Samples from Patients with Chronic Periodontitis. Journal of Clinical Periodontology, 30, 1046-1052. http://dx.doi.org/10.1046/j.0303-6979.2003.00425.x

[36] Kabashima, H., Nagata, K., Maeda, K. and Iijima, T. (2001) Presence of IFN-Gamma and IL-4 in Human Periapical Granulation Tissues and Regeneration Tissues. Cytokine, 14, 289-293. http://dx.doi.org/10.1006/cyto.2001.0879

[37] Suarez, L.J., Ocampo, A.M., Duenas, R.E. and Rodriguez, A. (2004) Relative Proportions of T-Cell Subpopulations and Cytokines That Mediate and Regulate the Adaptive Immune Response in Patients with Aggressive Periodontitis. Journal of Periodontology, 75, 1209-1215. http://dx.doi.org/10.1902/jop.2004.75.9.1209

[38] Fenton, M.J., Buras, J.A. and Donnelly, R.P. (1992) IL-4 Reciprocally Regulates IL-1 and IL-1 Receptor Antagonist Expression in Human Monocytes. Journal of Immunology, 149, 1283-1288.

[39] Orino, E., Sone, S., Nii, A. and Ogura, T. (1992) IL-4 Up-Regulates IL-1 Receptor Antagonist Gene Expression and Its Production in Human Blood Monocytes. Journal of Immunology, 149, 925-931.

[40] Vannier, E., Miller, L.C. and Dinarello, C.A. (1992) Coordinated Antiinflammatory Effects of Interleukin 4: Interleukin 4 Suppresses Interleukin 1 Production but Up-Regulates Gene Expression and Synthesis of Interleukin 1 Receptor 
Antagonist. Proceedings of the National Academy of Sciences of the United States of America, 89, 4076-4080. http://dx.doi.org/10.1073/pnas.89.9.4076

[41] Wong, H.L., Costa, G.L., Lotze, M.T. and Wahl, S.M. (1993) Interleukin (IL) 4 Differentially Regulates Monocyte IL-1 Family Gene Expression and Synthesis in Vitro and in Vivo. The Journal of Experimental Medicine, 177, 775-781. http://dx.doi.org/10.1084/jem.177.3.775

[42] Dickensheets, H.L. and Donnelly, R.P. (1997) IFN-Gamma and IL-10 Inhibit Induction of IL-1 Receptor Type I and Type II Gene Expression by IL-4 and IL-13 in Human Monocytes. Journal of Immunology, 159, 6226-6233.

[43] Murphy, K.M. and Reiner, S.L. (2002) The Lineage Decisions of Helper T Cells. Nature Reviews. Immunology, 2, 933944. http://dx.doi.org/10.1038/nri954

[44] Schroder, K., Hertzog, P.J., Ravasi, T. and Hume, D.A. (2004) Interferon-Gamma: An Overview of Signals, Mechanisms and Functions. Journal of Leukocyte Biology, 75, 163-189. http://dx.doi.org/10.1189/jlb.0603252

[45] Sallusto, F. and Lanzavecchia, A. (2009) Heterogeneity of CD4+ Memory T Cells: Functional Modules for Tailored Immunity. European Journal of Immunology, 39, 2076-2082. http://dx.doi.org/10.1002/eji.200939722

[46] Garlet, G.P., Martins Jr., W., Ferreira, B.R., Milanezi, C.M. and Silva, J.S. (2003) Patterns of Chemokines and Chemokine Receptors Expression in Different Forms of Human Periodontal Disease. Journal of Periodontal Research, 38, 210-217. http://dx.doi.org/10.1034/j.1600-0765.2003.02012.x

[47] Honda, T., Domon, H., Okui, T., Kajita, K., Amanuma, R. and Yamazaki, K. (2006) Balance of Inflammatory Response in Stable Gingivitis and Progressive Periodontitis Lesions. Clinical and Experimental Immunology, 144, 35-40. http://dx.doi.org/10.1111/j.1365-2249.2006.03028.x

[48] Dutzan, N., Vernal, R., Hernandez, M., Dezerega, A., Rivera, O., Silva, N., Aguillon, J.C., Puente, J., Pozo, P. and Gamonal, J. (2009) Levels of Interferon-Gamma and Transcription Factor T-Bet in Progressive Periodontal Lesions in Patients with Chronic Periodontitis. Journal of Periodontology, 80, 290-296. http://dx.doi.org/10.1902/jop.2009.080287

[49] Garlet, G.P., Martins Jr., W., Fonseca, B.A., Ferreira, B.R. and Silva, J.S. (2004) Matrix Metalloproteinases, Their Physiological Inhibitors and Osteoclast Factors Are Differentially Regulated by the Cytokine Profile in Human Periodontal Disease. Journal of Clinical Periodontology, 31, 671-679. http://dx.doi.org/10.1111/j.1600-051X.2004.00545.x

[50] Yoshinari, N., Kawase, H., Mitani, A., Ito, M., Sugiishi, S., Matsuoka, M., Shirozu, N., Ishihara, Y., Bito, B., Hiraga, M., Arakawa, K. and Noguchi, T. (2004) Effects of Scaling and Root Planing on the Amounts of Interleukin-1 and Interleukin-1 Receptor Antagonist and the mRNA Expression of Interleukin-1Beta in Gingival Crevicular Fluid and Gingival Tissues. Journal of Periodontal Research, 39, 158-167. http://dx.doi.org/10.1111/j.1600-0765.2004.00722.x

[51] Smith, D.E., Hanna, R., Della, F., Moore, H., Chen, H., Farese, A.M., MacVittie, T.J., Virca, G.D. and Sims, J.E. (2003) The Soluble Form of IL-1 Receptor Accessory Protein Enhances the Ability of Soluble Type II IL-1 Receptor to Inhibit IL-1 Action. Immunity, 18, 87-96. http://dx.doi.org/10.1016/S1074-7613(02)00514-9

[52] Yago, T., Nanke, Y., Ichikawa, N., Kobashigawa, T., Mogi, M., Kamatani, N. and Kotake, S. (2009) IL-17 Induces Osteoclastogenesis from Human Monocytes Alone in the Absence of Osteoblasts, Which Is Potently Inhibited by Anti-TNF-Alpha Antibody: A Novel Mechanism of Osteoclastogenesis by IL-17. Journal of Cellular Biochemistry, 108, 947-955. http://dx.doi.org/10.1002/jcb.22326

[53] Cardoso, C.R., Garlet, G.P., Moreira Jr., A.P., W.M., Rossi, M.A. and Silva, J.S. (2008) Characterization of $\mathrm{CD}^{+} \mathrm{CD} 25^{+}$Natural Regulatory T Cells in the Inflammatory Infiltrate of Human Chronic Periodontitis. Journal of Leukocyte Biology, 84, 311-318. http://dx.doi.org/10.1189/jlb.0108014

[54] Takahashi, K., Azuma, T., Motohira, H., Kinane, D.F. and Kitetsu, S. (2005) The Potential Role of Interleukin-17 in the Immunopathology of Periodontal Disease. Journal of Clinical Periodontology, 32, 369-374. http://dx.doi.org/10.1111/j.1600-051X.2005.00676.x

[55] Jiang, H., Harris, M.B. and Rothman, P. (2000) IL-4/IL-13 Signaling beyond JAK/STAT. The Journal of Allergy and Clinical Immunology, 105, 1063-1070. http://dx.doi.org/10.1067/mai.2000.107604

[56] Ohmori, Y., Smith Jr., M.F. and Hamilton, T.A. (1996) IL-4-Induced Expression of the IL-1 Receptor Antagonist Gene Is Mediated by STAT6. Journal of Immunology, 157, 2058-2065.

[57] Kohler, I. and Rieber, E.P. (1993) Allergy-Associated Iє and Fcє Receptor II (CD23b) Genes Activated via Binding of an Interleukin-4-Induced Transcription Factor to a Novel Responsive Element. European Journal of Immunology, 23, 3066-3071. http://dx.doi.org/10.1002/eji.1830231204

[58] Kotanides, H. and Reich, N.C. (1996) Interleukin-4-Induced STAT6 Recognizes and Activates a Target Site in the Promoter of the Interleukin-4 Receptor Gene. The Journal of Biological Chemistry, 271, 25555-25561. http://dx.doi.org/10.1074/jbc.271.41.25555

[59] Takeda, K., Tanaka, T., Shi, W., Matsumoto, M., Minami, M., Kashiwamura, S., Nakanishi, K., Yoshida, N., Kishi- 
moto, T. and Akira, S. (1996) Essential Role of Stat6 in IL-4 Signalling. Nature, 380, 627-630. http://dx.doi.org/10.1038/380627a0

[60] Shimoda, K., van Deursen, J., Sangster, M.Y., Sarawar, S.R., Carson, R.T., Tripp, R.A., Chu, C., Quelle, F.W., Nosaka, T., Vignali, D.A., Doherty, P.C., Grosveld, G., Paul, W.E. and Ihle, J.N. (1996) Lack of IL-4-Induced Th2 Response and IgE Class Switching in Mice with Disrupted Stat6 Gene. Nature, 380, 630-633. http://dx.doi.org/10.1038/380630a0

[61] Kaplan, M.H., Schindler, U., Smiley, S.T. and Grusby, M.J. (1996) Stat6 Is Required for Mediating Responses to IL-4 and for Development of Th2 Cells. Immunity, 4, 313-319. http://dx.doi.org/10.1016/S1074-7613(00)80439-2

[62] Huang, B.B., Bonish, B.K., Chaturvedi, V., Qin, J.Z. and Nickoloff, B.J. (2001) Keratinocyte CDw60 Expression Is Modulated by Both a Th-1 Type Cytokine IFN-Gamma and Th-2 Cytokines IL-4 and IL-13: Relevance to Psoriasis. The Journal of Investigative Dermatology, 116, 305-312. http://dx.doi.org/10.1046/j.1523-1747.2001.01242.x

[63] Baker, P.J., Evans, R.T. and Roopenian, D.C. (1994) Oral Infection with Porphyromonas gingivalis and Induced Alveolar Bone Loss in Immunocompetent and Severe Combined Immunodeficient Mice. Archives of Oral Biology, 39, 1035-1040. http://dx.doi.org/10.1016/0003-9969(94)90055-8 